\title{
Influence of Super Absorbent Polymers (Saps) on Irrigation Interval and Growth of Black Pepper (Piper Nigrum L.) in Nursery Management
}

\author{
K.G.A.I. Rasanjali ${ }^{1}$, C.S. De Silva ${ }^{2 *}$ and K.D.N. Priyadarshani ${ }^{3}$ \\ 1,2Department of Agricultural and Plantation Engineering, Faculty of \\ Engineering Technology, The Open University of Sri Lanka, Nawala, \\ Nugegoda, Sri Lanka \\ ${ }^{3}$ Intercropping and Betel Research Station, Dampelessa, Narammala, Sri \\ Lanka
}

\section{Abstract}

Drought stress is one of the most adverse limitations of local black pepper production in Dry and Intermediate zones of Sri Lanka. Application of Super Absorbent Polymers (SAPs) is hypothesized to result in the optimised use of water resources in these regions. A study was undertaken to examine the effect of different levels of irrigation intervals and different level of SAPs and then to find out the best treatment combination for growth of black pepper plants under nursery management. The experiment was conducted at Intercropping and Betel Research Station, Narammala. GK49 was the selected variety and Zeba (commercial name) was the selected SAP type. The experiment was carried out following a factorial layout based on Complete Random Design (CRD) with three replicates. The factors were three levels of irrigation intervals as 4, 8 and 10 days (T1 to T3) and four levels of SAPs as no Zeba, 1g, 1.5g and $2 \mathrm{~g}$ of Zeba (L1 to L4). Plant growth parameters were measured at two weeks interval and all the parameters were analysed by anova using SAS software. Statistical analysis had shown that there were

\footnotetext{
* Corresponding should be addressed to Prof. C. S. De Silva, Department of Agricultural and Plantation Engineering, The Open University of Sri Lanka, Nawala, Sri Lanka.
}

Email: csdes@ou.ac.lk

(D) https://orcid.org/0000-0003-3517-6914

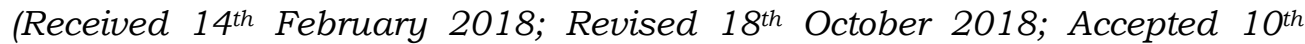
January 2019) (C) OUSL 
significant effects $(\mathrm{P}<0.05)$ of main factors and their interactions on plant parameters. Plant parameters were decreased with decreased Zeba amount and increased irrigation interval. In this study $2 \mathrm{~g}$ of Zeba with 4 and 8 days irrigation interval (L4T1, L4T2) and $1.5 \mathrm{~g}$ of Zeba with 4 days of irrigation interval (L3T1) treatments were the better treatments. However, considering the cost effectiveness $2 \mathrm{~g}$ of Zeba with 8 days irrigation interval (L4T2) treatment is recommended as the best treatment for increasing plant performances and decreasing water stress conditions to the plant. Therefore, the results of this study showed that SAPs can store and absorb a considerable amount of water and reduce unfavourable effects of water shortage on black pepper plants in nursery management.

Key words: Black Pepper, Irrigation interval, Plant parameters, Super Absorbent Polymers, Water stress.

\section{Introduction}

\section{Background and justification}

Black pepper (Piper nigrum L.) is a member of the Piperaceae family. Pepper is a perennial evergreen climbing vine, cultivated for its fruit, which is usually dried and used as a spice and seasoning. Black pepper is considered as the 'King of Spices' due to its high demand in the global context and also referred as 'Black gold' due to its higher prized trade. Black pepper is economically the most important and the most widely used spice crop of the world (Ravindran, 2000). Black pepper oil distilled from the fruits was used in perfumery. Export volume of Black pepper in Sri Lanka has increased from $7930 \mathrm{MT}$ in 2014 to $16,656 \mathrm{MT}$ in 2015 and export earnings have increased by $116 \%$ over previous years from Rs.Mn 9,029 to Rs.Mn, 19,543 in 2015 (DEA, 2015). India was the main buyer of pepper from Sri Lanka and purchases comprised of 54\% of pepper export in 2015 (DEA, 2015). Black pepper is imported usually for value addition purposes when local raw materials is inadequate and the low import of pepper in 2015 indicate that the value-addition companies have largely used local black pepper for their industries (DEA, 2015). 
In Sri Lanka, pepper is mostly grown in low and mid country wet and intermediate agro-climatic zones. Pepper is cultivated in an area of 31,997 ha (DEA, 2013). The spiciness of black pepper is due to the chemical piperine. Sri Lankan black pepper contains a higher amount of piperine which influences a premium price in international spice trade. High yielding ten local pepper selections have been identified by the Department of Export Agriculture of Sri Lanka, considering the characteristics such as high pungency, bold berries, continuous bearing habit, resistance to pest and diseases, etc. They are IW5, MB12, MW18, MW21, GK49, KW3O, KW31, KW33, TG7 and DM7. In addition to local types, two high yielding cultivars namely, Panniyur -1 (PAN) from India and Kuching (KU) from Malaysia were introduced to Sri Lanka in the 1970s. Butawerala, Dingirala and Kohukumburerala are high yielding hybrids which were newly released in 2015 (DEA, 2011).

Today, environmental conditions are so unpredictable due to climate change impacts and global warming. Recent studies using general circulation models, predicted increased temperature by 2050 in all regions of Sri Lanka which would induce high soil moisture deficit (De Silva et al, 2007). According to the Second National Communication (2011), in Sri Lanka temperature is expected to rise from $1.1-2.4{ }^{\circ} \mathrm{C}$ by 2100 , depending on the emission scenario. The trends for mean surface temperatures show a trend of $2.6{ }^{\circ} \mathrm{C} / 100$ years on average in annual average maximum temperature and 1.7 ${ }^{\circ} \mathrm{C} / 100$ years for annual average minimum temperature in Sri Lanka. Jiang and Huang (2001) reported that the increased frequency of temperature stress can disrupt the physiological processes of plants resulting in photosynthetic inhibition, lowered nitrogen anabolism and higher protein catabolism. Many researches stated that the temperature stress influenced on vegetative growth of crops and furthermore, Bita and Gerats (2013) reported that the vegetative plant parts show various morphological symptoms in response to heat stress. Water stress is also one of the major factors that influenced crop cultivations. Hatfield et al., (2015) reported that the growth and development of plants are affected by decrease in rain fall due to water stress. In the dry zone it is predicted by HadCM3 general circulation model that there would be a decrease in rainfall and an increase in soil moisture deficit, which would demand high irrigation water requirement (De Silva et al., 2007). 
According to the historical precipitation records over the monsoon regions around the globe, Kitoh et al., (2013) reported of a decreasing trend in the global land monsoon precipitation over the last half of the 20th century. When there is inadequate irrigation water plants will undergo stress and the productivity will be reduced. Therefore, it is essential to identify adaptation measures to cope with the situation. A crop like pepper needs regular watering to produce a high-quality product. Drought stress limits the plant growth of black pepper and creates difficulties in the nursery management. Areas with prolonged drought may not be suitable for cultivation unless there are adequate facilities for irrigation. Prevalence of sufficient rainfall during the flowering season is essential to ensure maximum pollination. Current climatic changes are increasing the incidence and severity of droughts. De Zoysa et al., in 2014 reported that, in 2011 approximately 55\% of the land area, mostly in the dry and intermediate zones, received less than $10 \%$ of the normal rainfall. Yazadani et al., (2007) reported that during severe droughts, when there was no water in the irrigation channels in the dry zone crops would fail. Panniyur has a good ability to tolerate drought conditions. But its quality is low and the incidence of diseases is high when compared with the local types (DEA 2011). Therefore, Sri Lanka pays much attention to promote local types. But the problem is its low drought tolerance ability. Dishani and De Silva (2016) reported that the farmers face problems regarding the availability of groundwater for agriculture when droughts are frequent. Therefore, effective and efficient water management is vital to overcome all these problems. Superabsorbent Polymers (SAPs) are more important in regions where water availability is insufficient (Maboko, 2006 and Monnig, 2005) and furthermore, Huttermann et al., (1999) reported that the SAPs prolonged water available for plant use when irrigation stopped. Yazdani et al., (2007) reported that using SAP in drought stress and water shortage conditions can improve the yield of soybean. Furthermore, Allahdadi (2002) reported that the SAPs compound help to increase the amount of available moisture and to reduce water stress of plants resulting in increased growth and plant performance. 


\section{Super Absorbent Polymers (SAPs)}

Super Absorbent Polymers have been established as a soil conditioner to reduce soil water loss and to increase crop growth. They can absorb and retain 1000 times more water than their original size and weight (Sojka and Entry, 2000). In this study SAPs were used to conserve the soil moisture so that irrigation interval could be increased to better use the limited irrigation water.

SAPs have been established as soil conditioner and it is vital to reduce soil water loss and increase crop yield. They are hydrophilic in nature and can retain water to 1000 times of its weight. As an environmental protection material, it is totally non-toxic, harmless and non-polluting. SAPs are used in agriculture for soil water retention, seed coating, soil-less cultivation, artificial turf, etc. It is important for improving seed germination and giving plants an early, healthy start, saving irrigation water and increasing crop and fruit yield. When water comes into contact with one of these polymeric chains of SAPs, it is drawn into the molecule by osmosis. Water rapidly migrates into the interior of the Super Absorbent Polymer (SAPs) network where it is stored. As the soil dries out, the polymer then releases up to $95 \%$ of the absorbed water back into the soil. SAPs are produced from acrylic acid and a cross-linker by solution or suspension polymerization. The type and quantity of cross-linker control both the swelling capacity and gel modulus. SAP, absorbent polymers, absorbent gels, super soakers, gel crystals, are materials that swell in water to form a clear gel made up of separate, individual particles. The product can improve soil quality, preserve water and resist drought, producing a better environment for plants to grow and develop.

Therefore, a study was carried out to understand the influence of different weight of organic based Super Absorbent Polymer (Zeba) on irrigation intervals and to identify the best treatment combination of irrigation interval and weight of super absorbent polymer for growth of black pepper plants under nursery management. 


\section{Methodology}

The study was carried out in a plant house at the Intercropping and Betel Research station, Department of Export Agriculture, Narammala, Dampelessa from January to December 2017. Local Black pepper type GK49 was selected for the experiment. Nursery media was prepared by using equal parts of top soil, sand, cow manure and coir dust. Ground runners were used to take cuttings. Amount of water that needs to fulfil the field capacity was measured by using volume basis method and pressure plate apparatus (Cresswell et al., 2008). Two nodal cuttings were used as planting material.

\section{Preparation of black pepper cuttings}

Ground runners of GK49 were used to take two node cuttings using a sharp knife. Leaves which were located below the $2^{\text {nd }}$ node were removed and half of the leaf which was located at the first node was removed to reduce transpiration losses by plant. Cuttings were treated with a Captan fungicide (N-trichloromethylthio-4cyclohexene-1) solution. Lower node was buried in the pot and the plants were immediately watered. The pots were kept in a propagator to induce shoot and root growth. Propagator was prepared in the plant house and $40-50 \%$ sunlight and $85-95 \%$ relative humidity were maintained. Propagator was opened after four weeks and the weeds were removed and sufficient amounts of water were added to the plants followed by closing the propagator for two more weeks and thereafter the polythene cover of the propagator was removed and plants were acclimatized to the environment. The plant house roof was covered using transparent polythene to avoid rainwater falling onto the plants.

\section{Experimental design}

Treatments were arranged in a Completely Randomized Design (CRD) with three replicates as a pot experiment. Each replicate consisted of forty plants. There are two factors of irrigation interval (T) and four weights of Zeba (Organic based super absorbent polymer) (L). Three irrigation intervals were applied as 4 days, 8 days, and 10 days. Four weights of Zeba were applied as $1 \mathrm{~g}$ per $1 \mathrm{~kg}$ of soil, $1.5 \mathrm{~g}$ per $1 \mathrm{~kg}$ of soil, $2 \mathrm{~g}$ per $1 \mathrm{~kg}$ of soil and for the control 
without super absorbent polymers. There were twelve treatment combinations after combining three watering intervals and four weights of super absorbent polymers.

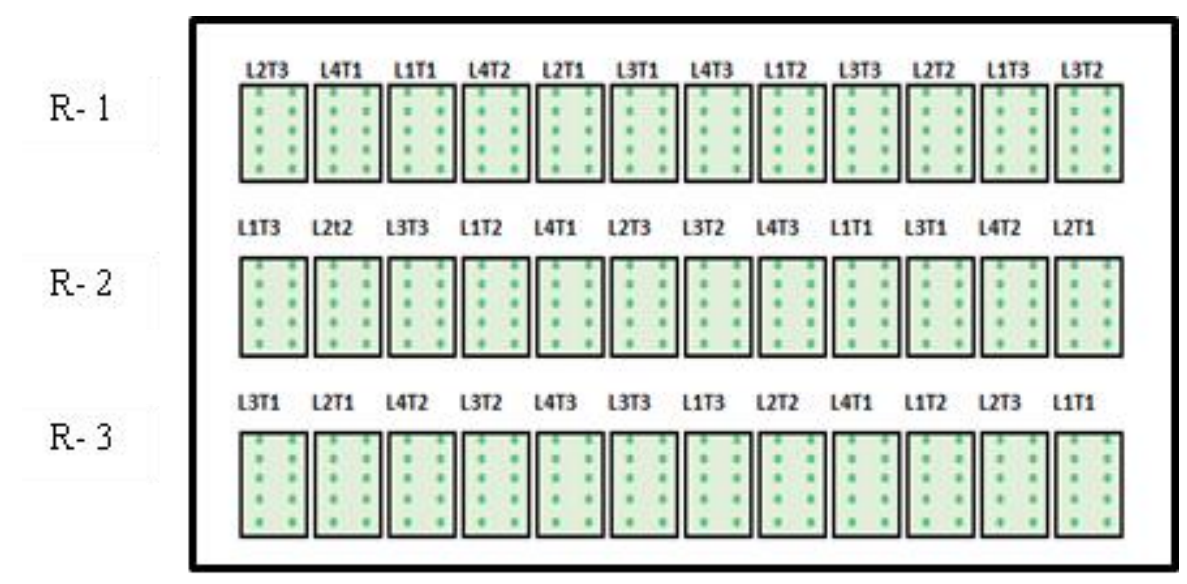

Figure 1: Field Layout

1. L1T1 - No Zeba +4 days of irrigation interval

2. L2T1 - $1 \mathrm{~g}$ of Zeba per $1 \mathrm{~kg}$ of soil +4 days of irrigation interval

3. L3T1 - 1.5g of Zeba per $1 \mathrm{~kg}$ of soil +4 days of irrigation interval

4. L4T1 $-2 \mathrm{~g}$ of Zeba per $1 \mathrm{~kg}$ of soil +4 days of irrigation interval

5. L1T2 - No Zeba +8 days of irrigation interval

6. $\quad$ L2T2 $-1 \mathrm{~g}$ of Zeba per $1 \mathrm{~kg}$ of soil +8 days of irrigation interval

7. L3T2 $-1.5 \mathrm{~g}$ of Zeba per $1 \mathrm{~kg}$ of soil +8 days of irrigation interval

8. $\quad$ L4T2 $-2 \mathrm{~g}$ of Zeba per $1 \mathrm{~kg}$ of soil +8 days of irrigation interval

9. L1T3 - No Zeba +10 days of irrigation interval

10. L2T3 $-1 \mathrm{~g}$ of Zeba per $1 \mathrm{~kg}$ of soil +10 days of irrigation interval

11. Lзт3 $-1.5 \mathrm{~g}$ of Zeba per $1 \mathrm{~kg}$ of soil +10 days of irrigation interval

12. L4T3 $-2 \mathrm{~g}$ of Zeba per $1 \mathrm{~kg}$ of soil +10 days of irrigation interval

\section{Parameters collected}

Plant parameters, survival rate, height of the plat, number of leaves, number of roots, root length, shot fresh weight, shoot dry weight, 
root fresh weight, root dry weight, root volume and leaf temperature were taken $1 \frac{1}{2}, 2,2 \frac{1}{2}, 3,3 \frac{1}{2}$, months after planting.

\section{Observation of Plant Parameters}

All the following data (Table 01) were subjected to Analysis of Variance (ANOVA) using SAS software package. Mean separation was done by Least Significant Difference Test (LSDT) at 0.05 level of probability.

Table 1: Plant parameters and the methods of measurement

\begin{tabular}{|l|l|c|}
\hline $\begin{array}{c}\text { Parameters } \\
\text { collected }\end{array}$ & \multicolumn{1}{|c|}{ Measurement techniques } & Units \\
\hline $\begin{array}{l}\text { Survival } \\
\text { rate }\end{array}$ & $\begin{array}{l}\text { After opening the propagator, survival rate } \\
\text { was calculated for each treatment }\end{array}$ & $\%$ \\
\hline $\begin{array}{l}\text { Height of } \\
\text { the plant }\end{array}$ & $\begin{array}{l}\text { Height of the plant was taken from randomly } \\
\text { selected two plants from each replicate by } \\
\text { using a tape. Height was measured from base } \\
\text { to tip of the plant. }\end{array}$ & $\mathrm{cm}$ \\
\hline $\begin{array}{l}\text { Number of } \\
\text { Leaves }\end{array}$ & $\begin{array}{l}\text { Number of new leaves of the plant was } \\
\text { counted by randomly selected two plants from } \\
\text { each replicate. }\end{array}$ & - \\
\hline $\begin{array}{l}\text { Number of } \\
\text { Roots }\end{array}$ & $\begin{array}{l}\text { Number of roots of the plant was taken by } \\
\text { using randomly selected two plants from each } \\
\text { replicate and counted number of roots arisen } \\
\text { from cutting surface. }\end{array}$ & - \\
\hline Root length & $\begin{array}{l}\text { Root length was measured using randomly } \\
\text { selected two plants from each replicates. Root } \\
\text { length was taken using grid method by using } \\
\text { 1cm grid paper. } \\
\text { Root length(R) Number of intercepts (N) X } \\
\text { Length conversion factor } \\
\text { Length conversion factor for 1cm grid paper is } \\
\text { taken as 0.7857 }\end{array}$ & $\mathrm{cm}$ \\
\hline $\begin{array}{l}\text { Shoot fresh } \\
\text { weight }\end{array}$ & $\begin{array}{l}\text { Fresh weight of randomly selected two plants } \\
\text { from each replicate was measured by using } \\
\text { electronic balancer. }\end{array}$ & $\mathrm{g}$ \\
\hline Shoot dry & \begin{tabular}{l} 
Shoots of plants were put in to the oven in \\
\hline
\end{tabular} & $\mathrm{g}$ \\
\hline
\end{tabular}




\begin{tabular}{|l|l|c|}
\hline weight & $\begin{array}{l}70^{\circ} \mathrm{C} \text { temperature until weights of the shoots } \\
\text { became constant. }\end{array}$ & \\
\hline $\begin{array}{l}\text { Root fresh } \\
\text { weight }\end{array}$ & $\begin{array}{l}\text { Root fresh weight of randomly selected two } \\
\text { plants from each replicate was measured by } \\
\text { using electronic balancer. }\end{array}$ & $\mathrm{g}$ \\
\hline $\begin{array}{l}\text { Root dry } \\
\text { weight }\end{array}$ & $\begin{array}{l}\text { Dry weight of roots was obtained by putting in } \\
\text { to oven at 70 } \text { C temperature until the weights } \\
\text { of roots became constant. }\end{array}$ & $\mathrm{g}$ \\
\hline $\begin{array}{l}\text { Root } \\
\text { volume }\end{array}$ & $\begin{array}{l}\text { Root volume was measured using 100 ml } \\
\text { gravimetric bottle }\end{array}$ & $\mathrm{cm}^{3}$ \\
\hline $\begin{array}{l}\text { Leaf } \\
\text { temperature }\end{array}$ & $\begin{array}{l}\text { Leaf temperature was measured of randomly } \\
\text { selected two plants from each replicate using } \\
\text { Infrared thermometer. }\end{array}$ & $\mathrm{OC}^{\mathrm{C}}$ \\
\hline
\end{tabular}

\section{Results and Discussion}

\section{Growth parameters}

\section{Plant survivability}

According to the Figure 2, treatment $2 \mathrm{~g}$ of Zeba with 4 days irrigation interval (L4T1) showed the highest percentage of survivability (95\%). The second and third highest survivability were observed in $1.5 \mathrm{~g}$ of Zeba with 4 days irrigation interval (L3T1) and $2 \mathrm{~g}$ of Zeba with 8 days irrigation interval (L4T2) treatment respectively. The treatment that consisted of no Zeba with a 10-day irrigation interval (L1T3) showed the lowest percentage of survivability (78.33\%). High weight of Zeba $(2 \mathrm{~g}, 1.5 \mathrm{~g})$ with 4 days of irrigation interval and 8 days of irrigation interval were very effective. Survivability of all the treatments without Zeba showed lower survivability percentage with all irrigation intervals. 


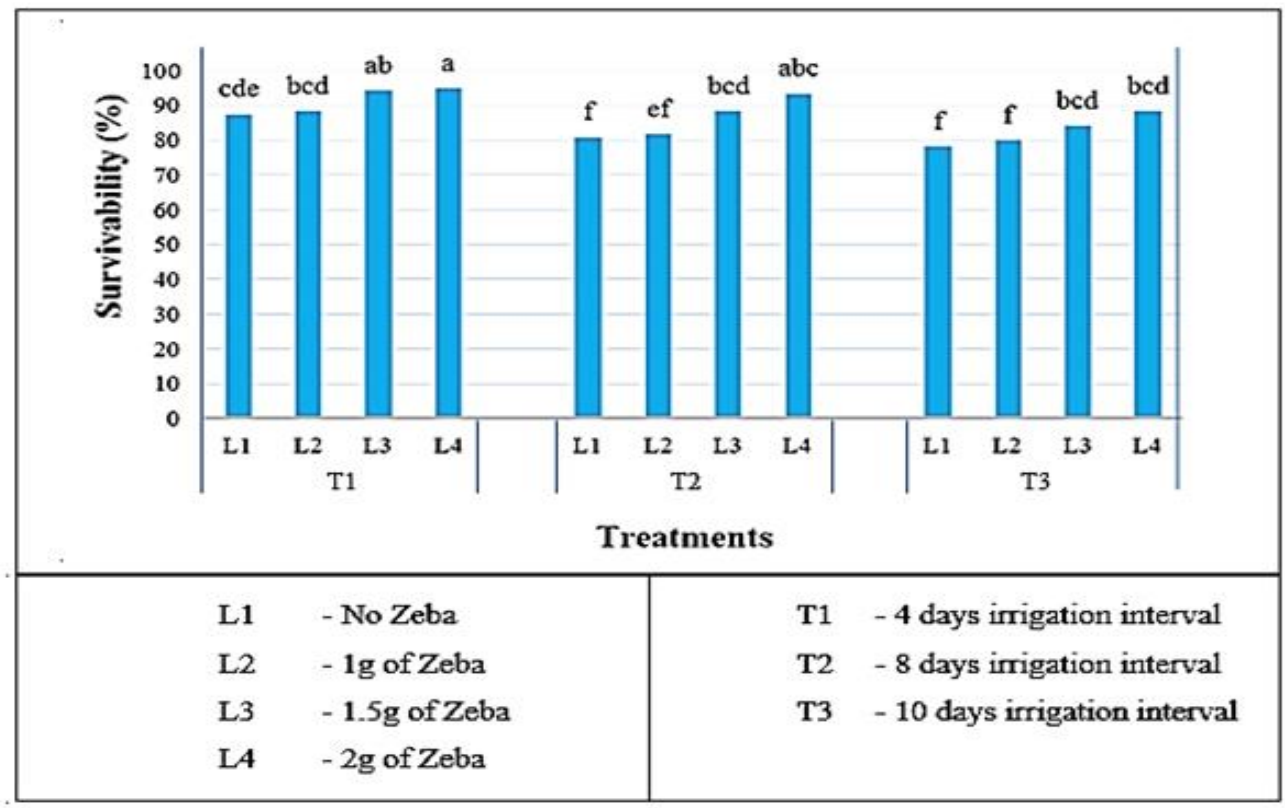

Figure 2: Plant Survivability in percentage.

(Treatments are significantly different if they do not share a letter (s) in common adjusted $P$ value $<0.05$ )

\section{Plant height}

Plant height showed an increasing trend from $2^{\text {nd }}$ month to $31 / 2$ month after planting. The treatment consisted of $2 \mathrm{~g}$ of Zeba with 4 days irrigation interval (L4T1) and showed the highest plat height but it was not significantly different from $1.5 \mathrm{~g}$ of Zeba with 4 days irrigation interval (L3T1) and $2 \mathrm{~g}$ of Zeba with 8 days irrigation interval (L4T2) treatments. The treatment that consisted of no Zeba with 10-day irrigation interval (L1T3) showed the significantly $(<0.05)$ lowest plant height (Table 2). All the treatments with Zeba showed better performances than the treatments without Zeba. Atiyea et al., (2013) reported that application of super absorbent polymers increases plant height and agreeed with the results of this research. Therefore, high weights of Zeba positively influence the plant height. All the treatments with longer irrigation interval resulted in lower height of the plants. Yang et al (2006) reported that reduction in water supply caused decrease in cell elongation. Furthermore Yang et al., (2006) and Haji Hassani et al., (2011) reported that drought 
stress via reduction in cell turgidity, cell growth, cell volume and number of stem cells reduced plant height.

Plant height was a dependable variable and according to the interaction analysis plant height varied with both factors, irrigation interval and Zeba weight. Therefore, there was a significant interaction effect $(\mathrm{P}<0.05)$ in treatment combination $(Z e b a * I r r i g a t i o n$ interval). Keshavars et al., (2012) also reported that various irrigation interval and super absorbent levels had significant effects on plant height.

\section{Width of the leaf}

Width of the leaf showed an increasing trend from $2^{\text {nd }}$ month to $31 / 2$ month after planting. The treatment consisted $2 \mathrm{~g}$ of Zeba with 4 days irrigation interval (L4T1) and showed the highest leaf width (Table 2). However, it was not significantly different from $2 \mathrm{~g}$ of Zeba with 8 days irrigation interval (L4T2) treatment and $1.5 \mathrm{~g}$ of Zeba with 4 days irrigation interval (L3T1) treatment. The treatment that consisted of no Zeba with 10-day irrigation interval (L1T3) showed the lowest leaf width. It could be due to the influence of soil moisture deficit. This result agrees with Keshavars et al., (2012) reporting that drought stress reduced the individual leaf size. Therefore, when irrigation interval was extended it resulted in leaves with low width and also all the treatments without Zeba resulted in lower width of leaf due to moisture stress to the plant. Therefore, the width of leaf was decreased in treatments in the following order; L4T1 $\geq$ L4T2 $\geq$ L3T1. According to the interaction analysis, width of the plant leaf varied according to both factors; irrigation interval and Zeba weight. Therefore, there was a significant interaction effect $(\mathrm{P}<0.05)$ in Zeba* Irrigation interval (treatment combination).

\section{Number of leaves}

The number of leaves showed an increasing trend from $2^{\text {nd }}$ month to $31 / 2$ month after planting. The treatment consisted of $2 \mathrm{~g}$ of Zeba with 4 days irrigation interval (L4T1) and showed the highest number of leaves (Table 2). However, it was not significantly different from the treatments of $2 \mathrm{~g}$ of Zeba with 8 days irrigation interval (L4T2) and $1.5 \mathrm{~g}$ of Zeba with 4 days irrigation interval (L3T1). The treatment that consisted of no Zeba with 10-day irrigation interval (L1T3) 
showed the lowest number of leaves. The number of leaves became low when irrigation interval was extended. This result agrees with Keshavars et al., (2012) finding as the number of leaves diminished with increase of the water deficit. Treatments of L4T1, L4T2 and L3T1 treatments were observed to be better treatments due to the high content of SAPs and suitable irrigation interval which provided enough moisture for plant growth and increased leaf number. The interaction effect of Zeba and irrigation interval significantly affected the dependable variable $(\mathrm{P}<0.05)$.

\section{Shoot fresh weight}

Shoot fresh weight showed an increasing trend from $2^{\text {nd }}$ month to 3 $1 / 2$ month after planting. The treatment of $2 \mathrm{~g}$ of Zeba with 4 days irrigation interval (L4T1) showed the highest shoot fresh weight and it was not significantly different from $1.5 \mathrm{~g}$ of Zeba with 4 days irrigation interval (L3T1), and $2 \mathrm{~g}$ of Zeba with 8 days irrigation interval (L4T2) treatments (Table 2). The treatment that consisted of with 10-day irrigation interval (L1T3) showed the significantly $(\mathrm{P}<0.05)$ lowest shoot fresh weight. Doraji et al., (2005) and Abayomi et al., (2002) reported that crop growth rate decreased with the increase of water stress as well as crop growth rate increased with increasing amount of SAPs in soil. The shoot fresh weight varied according to both factors and interaction effect of Zeba and the irrigation interval was significant $(\mathrm{P}<0.05)$.

\section{Shoot dry weight}

Shoot dry weight showed an increasing trend from $2^{\text {nd }}$ month to $31 / 2$ months after planting. The treatment L4T1 (2g of Zeba with 4 days irrigation interval) showed the highest shoot dry weight. However, it was not significantly different from $1.5 \mathrm{~g}$ of Zeba with 4 days irrigation interval (L3T1) and $2 \mathrm{~g}$ of Zeba with 8 days irrigation interval (L4T2) treatments. The treatment that consisted of no Zeba with 10-day irrigation interval (L1T3) showed the significantly $(\mathrm{P}<0.05)$ lowest shot dry weight (Table 2). Treatments with $2 \mathrm{~g}$ and $1.5 \mathrm{~g}$ of Zeba showed higher shoot dry weights than other treatments. These research findings can be justified with the Earl and Davis (2003) findings. They reported that active $\mathrm{O}_{2}$ causes damages to the cellular membranes under water stress conditions because of lipids peroxidization. Therefore, it finally leads to decrease of the plant 
chlorophyll content and results in reduced dry matter content of plant. According to the interaction analysis, dry weight of shoots varied according to both factors and interaction effect of Zeba and the irrigation interval was significant $(\mathrm{P}<0.05)$.

Table 2: Combined effect of irrigation interval and Zeba rate on the growth parameters of Black pepper

\begin{tabular}{|l|l|l|l|l|l|}
\hline \multicolumn{1}{|c|}{ Treatments } & $\begin{array}{c}\text { Plant } \\
\text { height } \\
\mathbf{( c m )}\end{array}$ & $\begin{array}{c}\text { Leaf } \\
\text { width } \\
\mathbf{( c m )}\end{array}$ & $\begin{array}{c}\text { Number } \\
\text { of } \\
\text { Leaves }\end{array}$ & $\begin{array}{c}\text { Shoot } \\
\text { fresh } \\
\text { weight } \\
\text { (g) }\end{array}$ & $\begin{array}{c}\text { Shoot } \\
\text { dry } \\
\text { weight } \\
\text { (g) }\end{array}$ \\
\hline L1T1 & $9.167^{\mathrm{d}}$ & $4.533^{\mathrm{e}}$ & $2.166^{\mathrm{d}}$ & $3.157^{\mathrm{e}}$ & $0.376^{\mathrm{e}}$ \\
\hline L1T2 & $5.467^{\mathrm{g}}$ & $3.967^{\mathrm{f}}$ & $2.333^{\mathrm{cd}}$ & $2.181^{\mathrm{g}}$ & $0.083^{\mathrm{g}}$ \\
\hline L1T3 & $2.833^{\mathrm{h}}$ & $2.417^{\mathrm{h}}$ & $1.333^{\mathrm{e}}$ & $1.711^{\mathrm{h}}$ & $0.032^{\mathrm{h}}$ \\
\hline L2T1 & $10.233^{\mathrm{c}}$ & $5.183^{\mathrm{d}}$ & $3.166^{\mathrm{b}}$ & $4.286^{\mathrm{c}}$ & $0.427^{\mathrm{d}}$ \\
\hline L2T2 & $7.083^{\mathrm{e}}$ & $4.533^{\mathrm{e}}$ & $2.166^{\mathrm{d}}$ & $3.713^{\mathrm{d}}$ & $0.278^{\mathrm{f}}$ \\
\hline L2T3 & $5.983^{\mathrm{f}}$ & $3.083^{\mathrm{g}}$ & $1.333^{\mathrm{e}}$ & $2.763^{\mathrm{f}}$ & $0.093^{\mathrm{g}}$ \\
\hline L3T1 & $13.016^{\mathrm{a}}$ & $7.517^{\mathrm{a}}$ & $4.666^{\mathrm{a}}$ & $5.300^{\mathrm{a}}$ & $0.688^{\mathrm{ab}}$ \\
\hline L3T2 & $8.983^{\mathrm{d}}$ & $6.567^{\mathrm{b}}$ & $3.000^{\mathrm{bc}}$ & $3.808^{\mathrm{d}}$ & $0.509^{\mathrm{c}}$ \\
\hline L3T3 & $7.083^{\mathrm{e}}$ & $5.733^{\mathrm{c}}$ & $2.000^{\mathrm{de}}$ & $2.142^{\mathrm{g}}$ & $0.273^{\mathrm{f}}$ \\
\hline L4T1 & $13.066^{\mathrm{a}}$ & $7.767^{\mathrm{a}}$ & $4.666^{\mathrm{a}}$ & $5.327^{\mathrm{a}}$ & $0.698^{\mathrm{a}}$ \\
\hline L4T2 & $12.900^{\mathrm{a}}$ & $7.550^{\mathrm{a}}$ & $4.000^{\mathrm{a}}$ & $5.232^{\mathrm{a}}$ & $0.693^{\mathrm{a}}$ \\
\hline L4T3 & $12.300^{\mathrm{b}}$ & $6.217^{\mathrm{b}}$ & $3.000^{\mathrm{bc}}$ & $4.840^{\mathrm{b}}$ & $0.658^{\mathrm{b}}$ \\
\hline Irrigation interval & $\mathrm{P}<0.05$ & $\mathrm{P}<0.05$ & $\mathrm{P}<0.05$ & $\mathrm{P}<0.05$ & $\mathrm{P}<0.05$ \\
\hline Zeba rate & $\mathrm{P}<0.05$ & $\mathrm{P}<0.05$ & $\mathrm{P}<0.05$ & $\mathrm{P}<0.05$ & $\mathrm{P}<0.05$ \\
\hline $\begin{array}{l}\text { Irrigation } \\
\text { interval }{ }^{*} \text { Zeba } \\
\text { rate }\end{array}$ & $\mathrm{P}<0.05$ & $\mathrm{P}<0.05$ & $\mathrm{P}<0.05$ & $\mathrm{P}<0.05$ & $\mathrm{P}<0.05$ \\
\hline CV\% & & & & & \\
\hline
\end{tabular}

L1: $0 \mathrm{~g}$ of Zeba, L2: $1 \mathrm{~g}$ of Zeba, L3: $1.5 \mathrm{~g}$ of Zeba, L4: $2 \mathrm{~g}$ of Zeba, T1: 4 day, T2: 8 day, T3: 10 day

\section{Root length}

The root length showed an increasing trend from $2^{\text {nd }}$ month to $31 / 2$ month after planting. The treatment of $2 \mathrm{~g}$ of zeba with 4 days irrigation interval (L4T1) showed the longest root length (Table 3). However, it was not significantly different from $1.5 \mathrm{~g}$ of Zeba with 4 days irrigation interval (L3T1) and $2 \mathrm{~g}$ of Zeba with 8 days irrigation interval (L4T2) treatments. The treatment that consisted of no Zeba with 10-day irrigation interval (L1T3) showed the lowest root length 
(Table 3). Root length varied according to both factors and interaction effect of Zeba and irrigation interval (Zeba*Irrigation interval) was significant $(\mathrm{P}<0.05)$.

\section{Root volume}

The root volume showed an increasing trend from $2^{\text {nd }}$ month to $31 / 2$ month after planting. The treatment of $2 \mathrm{~g}$ of Zeba with 4 days irrigation interval (L4T1) showed the highest root volume. However, it was not significantly different from $1.5 \mathrm{~g}$ of Zeba with 4 days irrigation interval (L3T1) treatment, $2 \mathrm{~g}$ of Zeba with 8 days irrigation interval (L4T2) treatment and $2 \mathrm{~g}$ of Zeba with 10 days irrigation interval (L4T3) treatment. The treatment that consisted of no Zeba with 10-day irrigation interval (L1T3) showed the lowest root volume (Table 3). The treatments which consisted of $1.5 \mathrm{~g}$ and $2 \mathrm{~g}$ of Zeba levels showed higher root volume in all irrigation intervals when compared with other treatments. Application of Zeba was more effective than control treatments. Extending irrigation interval resulted in lower root volume.

Table 3: Combined effect of irrigation interval and Zeba rate on root length and root volume of black pepper plant

\begin{tabular}{|l|l|l|}
\hline Treatments & $\begin{array}{l}\text { Root length } \\
(\mathbf{c m})\end{array}$ & $\begin{array}{l}\text { Root volume } \\
\left(\mathbf{c m}^{3}\right)\end{array}$ \\
\hline L1T1 & $30.433^{\mathrm{e}}$ & $0.578^{\mathrm{d}}$ \\
\hline L1T2 & $15.500^{\mathrm{g}}$ & $0.407^{\mathrm{de}}$ \\
\hline L1T3 & $10.306^{\mathrm{h}}$ & $0.284^{\mathrm{e}}$ \\
\hline L2T1 & $35.033^{\mathrm{d}}$ & $0.864^{\mathrm{c}}$ \\
\hline L2T2 & $30.163^{\mathrm{e}}$ & $0.536^{\mathrm{d}}$ \\
\hline L2T3 & $18.595^{\mathrm{f}}$ & $0.3715^{\mathrm{de}}$ \\
\hline L3T1 & $41.118^{\mathrm{a}}$ & $1.206^{\mathrm{a}}$ \\
\hline L3T2 & $39.146^{\mathrm{b}}$ & $0.963^{\mathrm{bc}}$ \\
\hline L3T3 & $29.152^{\mathrm{e}}$ & $0.586^{\mathrm{d}}$ \\
\hline L4T1 & $41.093^{\mathrm{a}}$ & $1.221^{\mathrm{a}}$ \\
\hline L4T2 & $40.856^{\mathrm{a}}$ & $1.208^{\mathrm{a}}$ \\
\hline L4T3 & $37.066^{\mathrm{c}}$ & $1.190^{\mathrm{ab}}$ \\
\hline Irrigation interval & $\mathrm{P}<0.05$ & $\mathrm{P}<0.05$ \\
\hline Zeba rate & $\mathrm{P}<0.05$ & $\mathrm{P}<0.05$ \\
\hline Irrigation interval ${ }^{\star}$ Zeba rate & $\mathrm{P}<0.05$ & $\mathrm{P}<0.05$ \\
\hline CV\% & & \\
\hline & 2.473 & 15.25 \\
\hline
\end{tabular}


L1: $0 \mathrm{~g}$ of Zeba, L2: $1 \mathrm{~g}$ of Zeba, L3: $1.5 \mathrm{~g}$ of Zeba, L4: $2 \mathrm{~g}$ of Zeba, T1: 4 day, T2: 8 day, T3: 10 day

Root volume varied according to both factors and interaction effect of Zeba and irrigation interval (Zeba*Irrigation interval) was significant $(\mathrm{P}<0.05)$.

\section{Leaf temperature}

The Treatment that consisted of no Zeba with 10-day irrigation interval (L1T3) showed the highest leaf temperature (Figure 3) and it could be due to high moisture stress to the plant. The treatment of $2 \mathrm{~g}$ of Zeba with 4 days irrigation interval (L4T1) showed the lowest leaf temperature. However, it was not significantly different from $2 \mathrm{~g}$ of Zeba and 8 days irrigation interval (L4T2) and $2 \mathrm{~g}$ Zeba and 10 days irrigation interval (L4T3). Therefore, treatments without Zeba and longer irrigation interval resulted in the increase of leaf temperature. When Zeba was present, moisture stress was relatively low.

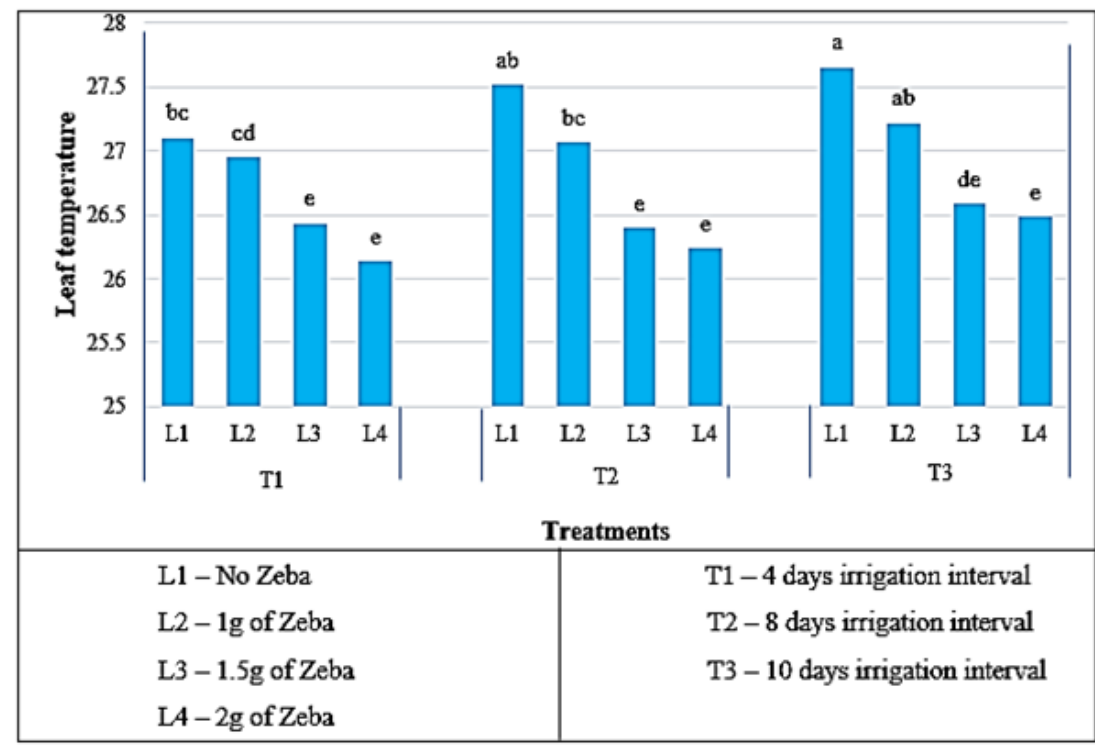

Figure 3: Leaf temperature $31 / 2$ months after planting

Treatments are significantly different if they do not share a letter (s) in common adjusted $\mathrm{P}$ value $<0.05$ 


\section{Cost Benefit analysis}

According to Table 4, Zeba cost increased with the weight of the Zeba used. Similarly, irrigation cost decreased with increase in irrigation interval. When the price of the pepper plant was 30 rupees (current price in Kurunegala (2017)), the highest income was obtained in treatment of $2 \mathrm{~g}$ of Zeba and 4 days irrigation interval (L4T1). But when the profit was considered the best treatment was $2 \mathrm{~g}$ of Zeba and 8 days irrigation interval (L4T2). Therefore, the use of Zeba helps to increase the irrigation interval from alternative days to 8-day irrigation interval which would be helpful in a drought situation.

Table 4. Cost benefit analysis of the treatments

\begin{tabular}{|l|l|l|l|l|}
\hline Treatments & $\begin{array}{c}\text { Cost for } \\
\text { Zeba/1000 } \\
\text { plants }\end{array}$ & $\begin{array}{c}\text { Cost for } \\
\text { plants }\end{array}$ & $\begin{array}{c}\text { Gross income } \\
\text { per 1000 } \\
\text { plants }\end{array}$ & $\begin{array}{c}\text { Profit (Gross } \\
\text { income- cost for } \\
\text { Zeba and } \\
\text { irrigation) }\end{array}$ \\
\hline L1T1 & & 9000 & 26250 & 17250 \\
\hline L1T2 & & 4500 & 24099 & 19599 \\
\hline L1T3 & & 3600 & 23499 & 19899 \\
\hline L2T1 & 1500 & 9000 & 26490 & 15990 \\
\hline L2T2 & 1500 & 4500 & 24500 & 18500 \\
\hline L2T3 & 1500 & 3600 & 24000 & 18900 \\
\hline L3T1 & 2250 & 9000 & 28230 & 16980 \\
\hline L3T2 & 2250 & 4500 & 26490 & 19740 \\
\hline L3T3 & 2250 & 3600 & 25250 & 19400 \\
\hline L4T1 & 3000 & 9000 & 28500 & 16500 \\
\hline L4T2 & 3000 & 4500 & 27990 & 20490 \\
\hline L4T3 & 3000 & 3600 & 26490 & 19890 \\
\hline
\end{tabular}

\section{Conclusions and Recommendations}

Treatment with $2 \mathrm{~g}$ of SAP with 4 days irrigation interval (L4T1) resulted in better plant performances than the other treatments. However, 2g of SAP with 8 days irrigation interval (L4T2) treatment and $1.5 \mathrm{~g}$ of SAP with 4 days irrigation interval (L3T1) treatment were not significantly different from L4T1 treatment. Therefore, considering cost effectiveness, $2 \mathrm{~g}$ of Zeba with 8-day irrigation interval (L4T2) is considered the best treatment to obtain promising results. All the treatments without Zeba showed poor plant 
performances. It could be due to the lack of soil moisture to the plant. Therefore, super absorbent polymers could be used successfully to overcome the water deficit when irrigation water is limited for Black pepper in nursery management.

\section{Reference}

Abayomi, Y. A., Aduloju, M. O., Egbewunmi, M. A., \& Suleiman, B. O. (2002). Effect of soil moisture contents and rates of NPK fertilizer application on growth and fruit yields of pepper (Capsicum spp.) genotypes, International Journal of Agi. Science, Vol 2. No.7 pp.651-663.

Allahdadi, I. (2002). Investigation the effect of superabsorbent hydrogels on reducing plant dry stress, $2^{\text {nd }}$ Specialized Training Course and Seminar on the Application of Superabsorbent Hydrogels in Agriculture, Iran Polymer and Petrochemical Institute, Tehran, Iran.

Atiyeh, O., \& Ebrahim, G. M. (2013). The effect of different levels of irrigation with superabsorbent (SAP) treatment on growth and development of Myrobalan (Prunus cerasifera) seedlings, African Journal of Agricultural Research, vol. 8 (17), 1813-1816. https://doi.org/ 10.5897/AJAR12.1649

Bita, C. E., \& Gerats, T. (2013). Plant tolerance to high temperature in a changing environment: scientific fundamentals and production of heat tolerance crops. Front. Plant Sci. 4, 273. doi: 10.3389/fpls.2013.00273. https://doi.org/10.3389/fpls.2013.00273

Climate change secretariat. (2010) strengthening capacity for climate change adaptation, ADB TA 7326 (SRI) Climate change secretariat ministry of Environment Colombo Sri Lanka.

Cresswell, H. P., Green, T. W., MsKenzie, N. J. (2008). The adequacy of pressure plate apparatus for determining soil water retention, Soil science society of America Journal, Vol. 72 (issue 1), 41, https://doi.org/10.2136/sssaj2006.0182

De Silva, C. S., Weatherhead, E. K., Knox, J. W. Rodrihuez-Diaz, \& J. A. (2007). Predicting the impacts of climate change-A case study of paddy irrigation water requirements in Sri Lanka. Journal of Agricultural Water Management 93(2007)19-29. Elsevier Publishers, Amsterdam, Netherlands. https://doi.org/10.1016/j.agwat.2007.06.0003 
De Zoysa, M. \& Inoue. M. (2014). Climate change impacts, agroforestry adaptation and policy environment in Sri Lanka. Open Journal of Forestry, Vol.04 No (05), Article ID: 50596, 17. https:/ / doi.org/10.4236/ojf.2014.45049

Department of Export Agriculture (2011) Black peer cultivationAnnual Report.

Department of Export Agriculture. (2013). Black pepper cultivationAnnual Report.

Department of Export Agriculture. (2015). Black Pepper CultivationAnnual Report.

Dishani, P. T. N. \& De Silva, C. S. (2016). Present status of water availability for agricultural production in the dry zone of Sri Lanka and the possible adaptation measures- A case study in Rajangana-Anuradhapura. Open University Research Sessions 2016, 168-171.

Dorji, K., Behboundian, M. H., Zegbe-Dominguez, J. A. (2005). Water relations, growth, yield and fruit quality of hot pepper under deficit irrigation and partial root zone drying. Scientia Horticultural, vol. 104, 137-149.

https://doi.org/10.1016/j.scienta.2004.08.015

Earl, H. J., \& Davis, R. F. (2003). Effect of drought stress on leaf and whole canopy radiation use efficiency and yield of maize. Agron. J. 95: 688-696. https://doi.org/10.2134/agronj2003.0688

Haji Hassani, N., Moradi Aghdam, A., Aliabadi Farahani, H., Hosseini, N., \& Rassaei Far, M. (2011). Three forage yields and its components under water deficit condition on delay cropping in Khoy zone (Iran). Advance in Environmental Biology, 5 (5): 847-852.

Hatfield, J. L., \& Prueger, J. H. (2015). Temperature extremes: effect on plant growth and development. Weather and Climate Extremes, 10, 4-10.

https:/ /doi.org/10.1016/j.wace.2015.08.001

Hutterman, A, Zommorodi, M., \& Reise, K. (1999). Addition of hydrogels to soil for prolonging the survival of Pinushalepensis seedlings subjected to drought. Soil and Tillage Res. 50, 295304. https://doi.org/10.1016/jwace.2015.08.001

Jiang, Y., \& Huang, B. (2001). Effects of calcium on antioxidant activities and water relations associated with heat tolerance in two cool-season grasses. J. Exp. Bot. 52, 341-349. https://doi.org/10.1093/jexbot/52.355.341 
Keshavars, L., Farahbakhsh, H., \& Golkar, P. (2012). The effect of drought stress and super absorbent polymer on morphphysiological traits of pear millet (Pennisetum glaucum), International research journal of Applied and basic science, vol., 3 (1), 148-154.

Kitoh, A., Endo, H., Kumar, K., Cavalcanti, I. F. A., Goswami, P., \& Zhou, T. 2013. Monsoons in a changing world: A regional perspective in a global context, Journal of geophysical research: atmospheres, vol. 118, 3053-3065. https://doi.org/10.1002/jgrd.50258

Maboko, M. M. (2006). Growth, yield and quality tomatoes (Lycopersicumesculentum mill) and lettuce (Lactucasativa L.) as affected by gelpolymer soil amendment and irrigation management. Master's Dissertation. Natural Agric. Sci. Uni Pretoria. P. 105.

Ministry of Environment. Second National Communication on Climate Change under the United Nations Framework Convention on Climate Change (UNFCCC). Democratic Socialist Republic of Sri Lanka, (2011).

Monnig, S. (2005). Water saturated superabsorbent polymers used in high strength concrete. Otto Graf J. 16:193-202.

Ravindran, P. N. (2000). Black pepper cultivation and its economics. Indian Journal of Areca nut spices and medicinal plants, 2, 7178.

Sojka, R. E., \& Entry, J. A. (2000). Influence of polyacrylamide application to soil on movement of microorganisms in runoff water. Environment pollution, 108(3), 405-412. https://doi.org/10.1016/S0269-7491(99)00194-3

Yang, X., Chen, X., Ge, Q., Li, B., Tong Y., Zhang, A., Liu, Z., Kuang, T., \& Lu, C. (2006). Tolerance of photosynthesis to photo inhibition, high temperature and drought stress in flag leaves of wheat: a comparison between a hybridization line and its parents grown under field conditions. Plant Science, 171, 389397. https://doi.org/10.1016/j.plantsci.2006.04.010

Yazdani, F., Allahdadi, I., \& Akbari, G. A. (2007). Impact of superabsorbent polymer on yield and growth analysis of soybean (Glysin max L.) under drought stress condition. Pak. J. Biol. Sci. 10, 4190-4196. https://doi.org/10.3923/pjbs.2007.4 190.4196. 